\title{
PENA DE MUERTE: ARGUMENTOS A FAVOR
}

\author{
Hugo Zepeda Coll \\ Profesor de Filosofía del Derecho y \\ Etica en la Escuela de Derecho de la \\ Universidad Católica del Norte y \\ otras Casas de Estudios Superiores.
}

Debo defender la tesis del derecho de la sociedad para aplicar la pena de muerte. Yo no podría decir que soy un partidario abierto de la pena de muerte, pero a veces es conveniente y hay que sostener algunas tesis, porque es pedagógico hacerlo. Además, de ninguna manera es una actitud inmoral sostener una u otra posición en este tema. Trataré de hacer como el coronel inglés del Puente del Río Kwai, que construyó a conciencia y de manera muy efectiva y sólida el puente que le encargaron sus enemigos.

Desgraciadamente, frente al problema de la pena de muerte se ha desatado una polémica que lleva siglos, y si bien es cierto que en un comienzo de la era civilizada no se discutió el derecho social para aplicar esta pena, ya en el Siglo IV existían tesis contrarias de la pena de muerte (tal como se deduce de algunos escritos de pensadores cristianos como Orígenes y Tertuliano).

Pero, sin duda alguna, el filósofo de mayor importancia fue San Agustín. San Agustín tiene también una posición un tanto ambigua. En una carta a un distinguido magistrado se manifiesta totalmente contrario a aplicar la pena de muerte, pero en su obra maestra "La Ciudad de Dios" deja abiertas algunas grietas por las cuales podría decirse que él doctrinariamente no rechaza la pena de muerte.

Y ésta ha sido la posición de la Iglesia Católica y en general del cristianismo. Los principales exponentes en el área protestante, como son Lutero y Calvino, fueron partidarios abiertos y sin reserva de la pena de muerte. Las reservas aparecen más en el sector católico del cristianismo. La Iglesia Católica jamás, hasta el día de hoy, ha discutido el derecho de la autoridad para aplicar la pena de muerte en casos extremos. La Iglesia Católica siempre ha considerado a la autoridad como delegataria por parte de Dios de todo aquello que atañe a la conservación del bien común, incluyendo también en ese derecho la aplicación de las penas, incluso la máxima. Y es así que los últimos documentos eclesiásticos, los del Concilio Vaticano II y el Catecismo de la Iglesia Católica, admiten en casos excepcionales la pena de muerte. Se reserva, sí, la Iglesia de decir que si se logra probar que hay otros remedios que pudieran sustituir la pena de muerte, habría que atenerse a éstos respecto a los delincuentes, y que no hay que excluir nunca el derecho a la misericordia que se ejerce a través de los indultos.

No vamos a invocar todavía a Santo Tomás de Aquino, que es el inspirador de la mayor parte de los teólogos moralistas de la Iglesia. Consideremos a un teólogo moral, 
el más importante que ha tenido la Iglesia Católica en el Siglo $X X$, Bernard Häring. Häring dice que el progreso de la humanidad, la madurez del hombre y su sensibilidad, no aconseja la pena de muerte, sino el uso de sustitutivos. Sin embargo, el Padre Häring reivindica -como todo teólogo católico- el derecho que tiene la autoridad en casos extremos para aplicar esta pena. Por lo demás, esta es la posición oficial de la Iglesia.

En todo caso, frente a la pena de muerte, los argumentos esgrimidos pasan de un extremo a otro. Se dan argumentos doctrinarios, pero a la vez se recurre a los pasionales; se va al orden de los principios teóricos y luego se dan razones prácticas; se plantean problemas de conciencia, se plantean problemas de conveniencia social, de desarrollo histórico. Hay quienes no rechazan en teoría la existencia de la pena de muerte, pero, sin embargo, la rechazan totalmente en la práctica por considerarla inútil. Es aquí donde se sitúa el problema, porque el peso de esta discusión, en los últimos 200 años, radica en las refutaciones a los dos más grandes filósofos que ha tenido Occidente, y que han sido los formadores del pensamiento cultural que hoy tenemos: Kant y Hegel, ambos partidarios de la pena de muerte. Kant, incluso, es talionista, o sea, sostiene prácticamente y en forma explícita la doctrina del Talión del "ojo por ojo, diente por diente". Hegel, en cambio, al plantear que la libertad es el fundamento del derecho, afirma su famosa doctrina de la "Lesión": el acto delincuencial, se entiende que grave, lesiona la estructura de la sociedad, la cual tiene derecho a mantenerse y, precisamente, a reparar el daño mediante la eliminación de su causante.

Posteriormente, sobre todo en Italia, hubo graves discusiones acerca de la pena de muerte. Está el célebre Beccaria, que es, sin duda alguna, quien por vez primera plantea sistemáticamente que no debe existir la pena de muerte, admitiéndola sí en dos casos: guerra y defensa propia. También lo siguen otros tratadistas italianos. Claro que hay algunas excepciones, como la de los positivistas, que aprueban la pena de muerte por razones un tanto peligrosas, pues sostienen que el ser criminal es un asunto innato, determinado, más allá de la responsabilidad de las personas, quienes no son responsables directos de lo que hacen, de tal manera que ha de considerarse al delincuente como un enfermo que - por razones medicinales- debe ser eliminado por la sociedad. Ésta es la más peligrosa de las razones esgrimidas por los que aprueban la existencia de la pena de muerte.

Hoy por hoy, encontramos en el elenco de los penalistas una abrumadora mayoría en pro de la abolición. En el resto de los cultores de las disciplinas jurídicas las opiniones están divididas. Respecto del pueblo, ocurre algo muy especial, ya que aquí en Chile ha habido una evolución. En nuestro país, hasta hace 30 años atrás, cada vez que alguien era condenado a muerte el pueblo variaba su manera de pensar: cuando el delito se cometía se pedía la pena de muerte y después se pedía que se indultara al reo. Esto ha ido cambiando, más o menos desde el año 1992, con motivo del indulto de que fueron objeto los peruanos que asesinaron a dos jóvenes en Arica, y ahora en el caso de Cupertino Andaur.

A mí me parece que el problema radica fundamentalmente en el concepto de la pena. La pena cumple varios éectos: un efecto retributivo, un efecto disuasivo y un efecto medicinal reeducativo. La doctrina abolicionista le da principalidad al efecto reeducativo de la pena, sin excluir el efecto retributivo y excluyendo el disuasivo. 
Respecto del efecto retributivo, hay quien califica esta pena como una especie de venganza social y, para eliminar toda contradicción lógica, dice que ha de rechazarse la idea de una retribución absoluta y que debe admitirse una retribución relativa, analógica y moral.

Ahora bien, cuando el carácter reeducativo de la pena pasa a tener principalidad provoca también una contradicción lógica que es necesario superar. Se dice: no a la pena de muerte, pero sí a la efectividad del presidio perpetuo. Si la pena tiene como principalidad el carácter reeducativo, lograr la reinserción social del reo, el presidio perpetuo pasa a ser injusto, porque eventualmente está la reeducación y, entonces, ¿cómo, si se ha reeducado al criminal, se le sigue conservando tras las rejas? De modo, entonces, que los abolicionistas siempre tendrán que ser partidarios de que la persona condenada a presidio perpetuo pueda obtener la libertad luego de algunos años de presidio, probada que sea la reeducación. Incluso el senador Piñera, que acaba de presentar un proyecto para hacer efectivo el presidio perpetuo, ha dicho: "Bueno, claro que si a los 30 años... ". O sea, se pasaría de los 20 a los 30 años, pero de todas maneras se deja siempre la posibilidad de que la reeducación impida el que haya presidio perpetuo. Por lo tanto, de hecho, una vez abolida la pena de muerte, no existe el presidio perpetuo en la práctica, y es natural que no exista si se estima que el efecto principal de la pena es reeducativo, es la reinserción del reo en la vida social.

Además, aquí surge el problema de la retribución, que ése es el fin principal y clásico de la pena. Si se estima que esta pena es una venganza social, entonces toda pena es una venganza, incluso el presidio. El mismo orden moral, al ser retributivo, no sería más que una venganza. Entonces, no se admite la retribución respecto a la pena de muerte, pero sí respecto al presidio.

Ahora bien, si aceptamos la teoría de que toda pena es reeducativa y aplicamos con estricta lógica los principios para extraer las conclusiones, llegamos a otra consecuencia. Si la pena es reeducativa, todas las penas deberían ser indefinidas en el tiempo, hasta que no se produce la reeducación y la reinserción social del reo de acuerdo a una calificación de la autoridad. Nuevamente, la autoridad de la sociedad se va a arrogar el derecho a determinar cuándo se está reeducado, pues no puede bastar una mera promesa de arrepentimiento. Por eso, si la pena tiene fundamentalmente un efecto reeducativo, toda pena tendría que ser indefinida.

El problema de la supresión de la pena de muerte provoca también una distorsión de penas. ¿Qué distorsión de penas? En suma, pasa a ser difícil la evaluación de las penalidades de los diversos tipos delictivos que se cometen en la sociedad. En el caso de Cupertino Andaur, su pena de muerte fue conmutada por la de presidio perpetuo, la misma pena a la que están condenados sus cómplices, y como todos saben muy bien, la complicidad es un grado de participación menor que la autoría. Basta el buen criterio natural del ser humano para darse cuenta de que la equiparación de las penas por delitos diferentes o por diversos grados de participación en un mismo hecho delictivo, provoca una distorsión en el orden de conceptos. Algún cómplice de Andaur podría llegar a pensar: "Bueno, yo no me atreví a violar. Debería haberlo hecho".

Menciono algunos casos concretos, en nuestra legislación, respecto a las técnicas de aplicación de penas. Don Feliciano Palma, un caballero que cometió una serie de estafas, arriesga aproximadamente $35 \circ 40$ años de cárcel. Por la técnica jurídica, no podrá salir antes de 15 ○ 20 años. En cambio, los sres. peruanos que 
asesinaron abyectamente a los jóvenes en Arica, teóricamente, como no tienen prontuario anterior, podrían salir a los 10 años. O sea, podría ser más castigado Feliciano Palma que ellos, en circunstancia de que no hay comparación en la calidad del delito cometido por uno y otros. Este problema de distorsión de la pena ¿a qué obligaría? A tener que cambiar todo el sistema penal, comenzando con los indultos. Yo creo que lo justo hubiera sido que el Presidente de la República hubiese indultado o conmutado la pena de los cómplices del señor Andaur.

Ahora, ¿qué ocurre? Pasemos al carácter disuasivo de la pena que se infringe. Los abolicionistas consideran que no tiene carácter disuasivo, que quien está determinado a cometer un homicidio lo comete de todas maneras, haya o no haya pena de muerte. Desgraciadamente, es muy difícil una verificación empírica de esta afirmación. Stuart Mill, el padre del liberalismo, el año 1868, en la Cámara de los Comunes, dijo: "Eso es imposible de determinar, porque nadie está en lo profundo del espíritu ni de la conciencia de los hombres". Se dice que no disuade, mas iy si fuera al revés? La única encuesta que leí el otro día en el diario, un artículo de un ex Director del Hospital Psiquiátrico Horwitz, de Santiago, en cuanto a si es disuasiva o no la pena de muerte, dice que sí disuade. Se presentó el año 1982 a la Cámara de Representantes, respecto de los años 60-69. En esos años, en algunos estados norteamericanos se suprimió la pena de muerte. El año 60 , mientras había pena de muerte, se cometían 8.400 y tantos homicidios. Nueve años más tarde, éstos llegaron a 14.700 , casi el doble: por lo tanto, la no existencia de la pena de muerte, según esta encuesta, habría influido para que se cometiesen más homicidios. Por lo demás, una distinguida abogada, una de las primeras feministas que ha tenido Chile, era contraria a la pena de muerte y ahora viene de vuelta. Incluso me han manifestado que el propio Dr. Otto Dörr, que incluso ha escrito un libro en que rechaza la pena de muerte, también ha tenido una suerte de evolución en sentido contrario. Después veremos las razones de esta evolución.

Garófalo me parece que es el que dice que no hay que llamar propiamente pena a la pena de muerte. Muchos pensadores sostienen que en realidad aquí estaríamos en presencia de la defensa social, una especie de analogía entre la defensa privada y la defensa social. Santo Tomás pareciera sostener esta tesis. Santo Tomás aprueba el tiranicidio, y analógicamente es asimilable la pena de muerte a las razones que han de concurrir para el tiranicidio: la defensa del cuerpo social, afectada tanto por los actos arbitrarios del tirano cuanto por los actos delictuales más graves. El argumento que para mí tiene más valor es éste: todos reconocemos el derecho a la legítima defensa. En la medida en que se restringe el ámbito de aplicación de la pena de muerte (como en Chile, donde no está abolida la pena de muerte, pero si está restringido su ámbito de manera casi absoluta, por cuanto doctrinariamente el Presidente de la República dice que no es partidario de la pena de muerte), se dictan leyes, ampliando incluso a través de la presunción el derecho a la legítima defensa. Cuando en Chile se aplicaba la pena de muerte, para que procediese jurídicamente la legítima defensa, ésta debía cumplir una serie de requisitos copulativamente considerados. Además, también era difícil probarla (sobre todo en los caso de asaltos en las casas de noche) por parte de quien ejercía la legítima defensa. Desde hace 3 años, en este país se han dictado leyes por las cuales estos requisitos se presumen. Esta ampliación, incluso vía presunción, del ámbito de la legítima defensa, se produce precisamente, porque el ciudadano se encuentra inseguro, y la inseguridad ciudadana es siempre peligrosa para la mantención de un Estado democrático de derecho. La inseguridad es muchas veces el caldo de cultivo de 
la renuncia de uno de los más grandes dones que los dioses han dado los hombres, como dice Don Quijote, que es la libertad.

Además, mientras la sociedad no tiene derecho a matar, el particular ve ampliada -vía presunción- su derecho a la legítima defensa ¿A qué estamos llegando? Simplemente estamos privatizando el derecho a matar. ¿Por qué? Porque yo aseguro que dentro de poco se dictarán nuevas leyes al respecto, facilitando el uso de armas, contratar guardaespaldas, etc. ¿Alguno de nosotros podría criticar mañana al Dr. Zamorano si electrifica por un cable de alta tensión la entrada a su casa, y a raíz de eso muere una persona que iba a robar cerezas, o un niño chico que iba a buscar una pelota? Evidentemente, comprenderíamos la situación. Además, ha ocurrido. Ocurrió en el caso de un anciano que fue asaltado en su predio; al poco tiempo salieron en libertad los asaltantes; volvieron a cometer otro asalto y otro más por tercera vez y, entonces, creyendo que eran los mismos asaltantes, disparó y mató a un niño de 11 años.

Ahora, hagamos un análisis filosófico por un momento. Vamos a usar a un padre indiscutido del liberalismo y del contractualismo como es John Locke. Locke plantea que el hombre tiene tres derechos naturales, incluso antes de organizarse en el Estado. Precisamente los hombres organizan el Estado a través de un pacto para garantizar estos derechos. De modo que gobernante que no garantice estos derechos, los ciudadanos están facultados para deponerlo. ¿Y cuáles son estos derechos? The right of life, the right of liberty and the right of estate. El derecho a la vida, el derecho a la libertad y el derecho a la hacienda, más que a la propiedad. Ninguna pena, aunque fuese por un delito atroz, podía incluir de modo anexo la confiscación de bienes. No confundamos la confiscación de bienes con la indemnización por un delito, que son dos figuras distintas. No puede haber confiscación de bienes, de ninguna manera, ya que esto iría en contra de un derecho natural del hombre. Mas, muy respetable es el derecho a la hacienda, el derecho de propiedad, pero es un derecho en todo caso derivativo de las personas, después de la vida y después de la libertad. Sin embargo, fue la primera conquista que hicieron quienes luchaban por la morigeración de las penas, la supresión de la confiscación de bienes.

Ahora, se plantea moralmente el derecho absoluto de la vida. Les advierto que en todas las declaraciones internacionales, empezando por la del año 1948 de la ONU, la reforma que se hizo a esa misma carta el año 1957 y la resolución de la Comisión Interamericana de Juristas del año 1969, se admite y se dice que nadie puede ser privado injustamente de la vida. O sea, se reproduce más o menos la tesis católica. Colombia y Uruguay, en las conferencias del 57 y del 69, pidieron la abolición total de la pena de muerte, lo que no fue concedido. Se opusieron las grandes potencias: EE.UU., la Unión Soviética e Inglaterra; Francia, a pesar de que en esa época tenía pena de muerte, mantuvo silencio. Sin embargo, se habla en favor de la vida, pero no se la excluye: nadie puede ser privado injustamente de la vida. $Y$, además, en la Conferencia del año 69 se establece que los países que ya suprimieron la pena de muerte, no la deben restablecer, y que los que ya la tengan no la deben ampliar a otros delitos.

No existe el derecho de la sociedad para privar a nadie de la vida, porque la vida es un valor absoluto. Ni justa ni injustamente, ni el hombre inocente ni el criminal pueden privar de la vida, y el Estado tiene que proteger la vida e impedir que esta vida 
sea privada. Aceptemos este argumento, no se puede privar de la vida en sentido absoluto. ¿Y qué pasa con la libertad? ¿no es acaso un valor supremo la libertad? ¿Por qué? Porque los que somos libertarios decimos muchas veces que hay que dar la vida por defender la libertad, no hipotecar la libertad para conservar la vida. Toda pena privativa de la libertad, si le damos carácter absoluto a la libertad, también sería injusta, y habría que plantear desde ya que las penas serían todas alternativas. Esto que estoy diciendo no es algo utópico. Hay movimientos, actualmente en Europa, en que se está planteando esta teoría: luchar por la supresión del presidio perpetuo por considerarlo inhumano, con argumentos muy parecidos a los de la supresión de la pena de muerte. ¿Acaso el día de mañana no se va a pedir también que todas las penas sean alternativas?

¿Pero qué ocurre frente a toda esta situación? Frente a esta situación ocurre un segundo hecho que es importante. El Estado dice que no puede privar de la vida a nadie, ni justa ni injustamente, ni permitir que se prive la vida. Sin embargo, hay doctrinas e incluso ya algunas leyes en que se permite la eutanasia, y se discute si el médico facultativo, si le es pedida la eutanasia, puede hacer una objeción de conciencia o no. Hay ciertas partes en que se sostiene que debe aplicar la eutanasia si le es pedida. Reconozco que en materia legislativa todo esto está en ciernes todavía, pero si hay doctrinas al respecto, ¿no podría aplicarse lo mismo al suicidio, al aborto?.

De ahí entonces que la pena de muerte, además, y este es el último argumento, analógicamente hablando, por supuesto, no es otra cosa que una subrogación que hace la autoridad de la sociedad, la autoridad del Estado, para castigar a quien privó injustamente de la vida a una persona débil que no pudo defenderse. De todos modos, a veces valoramos más una reacción cuasi zoológica como la defensa propia, que la resolución racional de la condena a muerte hecha por la autoridad.

Ahora, todo el mundo tiene derecho a que su vida sea respetada y si ella es privada injustamente, puede haber un castigo ejemplar, retributivo y similar, congruente con la gravedad del hecho, el de privar la vida, porque nosotros estamos en un medio social y a él nos integramos.

En todo caso, la discusión va a seguir siempre. Ahora el Profesor Náquira va a rebatir algunos puntos de vista. Evidentemente que ésta es una discusión sin fin, en la que hay mucho de pasional.

Creo que para la tranquilidad, y con esto termino, de la sociedad, para el imperio en definitiva del derecho, de un Estado de derecho, así como tenemos que proteger la libertad de los ciudadanos, incluso frente a las arbitrariedades del poder, tenemos que proteger la vida en forma irrestricta de quienes han sido débiles y no han podido defenderse de las injustas agresiones. 